\title{
Impact of Cash Holding on Firm Performance with Moderating Role of Corporate Governance
}

\author{
Naveed Anjum \\ PhD Scholar, Department of Management Sciences \\ University of Swabi \\ naveedicma@gmail.com \\ Dr. Faisal Khan \\ Assistant Professor, University of Swabi \\ faisalkhan@uoswabi.edu.pk \\ Shoib Hassan \\ PhD Scholar, Comsats University, Islamabad \\ shoaibhasan83@yahoo.com \\ Dr. Muhammad Arif \\ Assistant Professor, University of Swabi \\ dr.arif@uoswabi.edu.pk
}

\begin{abstract}
The main aim of this research is to analyze the association between cashholding and firm performance with moderating role of corporate governance. For the purpose of analysis, secondary data of 145 non-financial firms listed at Pakistan Stock Exchange (PSX) is taken from 2006-2017. The dynamic Generalized Method of Moments (GMM) is applied to cater the problem of unobserved heterogeneity. The results of this study suggest that cash holding has a significant impact on firm performance. Moreover, corporate governance significantly moderates the relationship between cash holding and firm performance.
\end{abstract}

Keywords: Cash Holding, Corporate Governance, Pakistan Stock Exchange, Generalized Method of Moments

\section{Introduction}

The issues related to cash-holding and firm performance have received substantial consideration after the global financial crisis. The cash held by the business organizations not only affect the liquidity but also financial performance (Harford, Klasa \& Maxwell, 2014; Huang, Lambertides \& Steeley, 2016). Whenever a large amount of cash is held by a company, it will result in increasing the opportunity cost as well as decreasing the firm's performance. On the other hand, when too little amount of cash is held by the company, it may create deficits for meeting the operational costs thus reducing firm's performance (La Rocca \& Cambrea, 2019). Hence it is important that the amount of cash a company is holding should be adequate for covering up regular operating expenses, fulfill liquidity requirements, financing future projects (if needed) and 
for contingency purposes (Doan, 2020). Only having sufficient cash for these purposes can help improve the financial performance of firms. According to the research of Graham \& Leary (2018) on US firms, $13 \%$ of the sum of all assets in case of large firms constitute cash and cash equivalents. In another study, it was found by Al-Najjar and Clark (2017) that in UK, total assets of the firms constitute 9\%, on average, of cash. While in context of Pakistan, cash and cash equivalents makes up to more than $10 \%$ of total assets, on average (Ali \& Ullah, 2016). All these studies show that cash is considered a significant asset and firm's performance is directly linked to it. Therefore, cash management is considered to be a key issue for corporate financial policies. In the similar vein, the separation of ownership and control has given rise to conflict of interest between the managers and shareholders commonly known as agency problem.

In order to cater agency problem and risks faced by the business organization, the board of directors play an important role by implementing the governance mechanism. This situation has therefore highlighted the importance of corporate management team in firms who can take care of the various risks faced by the business organizations. Corporate governance-related issues became prominent in the 1990s, when South America and East Asia were hit with financial crisis followed by a series of corporate scandals (e.g. demise of WorldCom and Enron) in other countries like US. Hence, corporate governance has gained significant importance in both developed as well as developing countries in the recent years. Economist view corporate governance as a tool used for sustaining the growth of businesses and the overall economy. According to the argument put forth by Kren (2016), the increasing need for nations to acquire financial resources both domestically as well as internationally has made it critical to implement corporate governance mechanisms. In this age of globalization, corporate governance mechanisms are playing a vital role in strengthening private sector and enhancing its contribution to the social and economic progress (Ducassy \& Montandrau, 2015).

Recent emphasis on effective implementation of corporate governance in organizations has significantly influenced operating activities of many companies (Ducassy, 2015; Haan \& Vlahu, 2016). As depicted in the black-box argument, firms are quite similar in their behavior towards production counters. Hence, the overall focus of all activities taking place in a firm is directed towards profit generation and maximization. However, it is also believed that not only the economic and production related concerns drive corporate governance motivations but behavioral elements related to firm's performance also plays an important role (Francis et al., 2015). Many studies examined the corporate cash-holdings to determine the link of financial performance with cash-holdings in case of different firms (Kim et al. 2011; Campello, 2011; Al-Najjar, 2013). Most of these studies assumed that industry/sector and firm characteristics such as investment in fixed assets, leverage, firm size, growth opportunities and cash flow etc. determine cash-holdings. Additionally, the study of Sheikh and Khan (2016) also depicted that it is not the firm characteristics only that determine cash-holdings but managerial characteristics such as CEO duality, age, gender etc., also play an important part. Apart from these, corporate governance is also seen to impact value of cash-holdings in any firm. Dittmar and Mahrt-Smith (2007) found in their study that excessive cash-holdings are valued more by investors in well-governed firms as compared to poorly governed firms.

After 2008's Global Financial Crisis, the issue of corporate governance has been under critical review in context of many countries. Asian economies, similar to other financial markets, also experienced a period of economic recession consequently affecting the political and economic atmosphere (Jabbouri \& Almustafa, 2020). Hence, Pakistani listed firms provides a good sample 
for examining the transition after Global Financial Crisis in Asian context (Abdumavlonov, 2012). Since the prior literature is based on developed economies having strong legal and governance structure, it would be interesting to analyze the effectiveness of corporate governance in developing economies which are characterized by information asymmetry, lack of investor protection and weak form of market efficiency. Moreover, analyzing literature also suggest that such mechanisms are different for financial and non-financial sectors. Moreover, majority of previous research studies have focused on financial sector. Since their nature of business, governance structure and regulations are different from the non-financial sector.Thus the current research aims to address the issue that how cash holding affect the firm performance with moderating role of corporate governance.

\section{Literature Review}

\subsection{Cash Holding and Firm Performance}

The terminology of cash-holding is used to indicate managerial decision regarding the amount of cash and cash equivalents that a firm must hold. It is important because such decisions impact the corporate value as well as firm's efficiency and dynamics. Every firm has its own different reason for holding cash which depicts their major motives, as indicated by past studies. Companies, for example, need cash for making daily transactions because cash is a direct mean of exchange; however, companies vary in their demand for cash (Bates et al. 2009). In cases when firms run out of liquid assets or funds required to suffice their daily operations, they tend to acquire funds from external sources such as the capital markets, or restrict dividend payouts, or turn their existing assets liquid or put a cut on investment opportunities available to them (Nguyen et al., 2019). However, each and every of these activities have their own costs. Companies not only required cash for feeding their daily transactions, but it is also needed for uncertain circumstances such as unexpected spending needs. As per the research of Ferreira and Vilela (2004), cash is used by firms for financing their investing and financial activities when other external sources of funds are way too costly to afford. Nevertheless, companies have varying demands for keeping cash reserves which is situational and also depends on specific objectives of a firm.

Managers usually take advantage of information asymmetry exists between them and the shareholders by using dividend payment policy to send good signals to investors regarding prospects of the firm. Harford (2008) found in his study that dividend payment is deemed as more positive signal as compared to purchasing treasury securities by making use of cash. It is because when a company pays dividend, it depicts firm's commitment to higher payments in future as well, whereas purchasing treasury securities is seen as a this year's activity and has no future implications. It is the discretion of managers to choose between options of withholding cash or payingdividends. Hence, the availability of more free cash flow may cause managers to exercise their discretion against the best interest of shareholders (Jensen, 1986). Harford (2008) confirmed in his study that firms having large amounts of cash-holdings tend to use it for acquiring other businesses. In addition to this, Bolton et al. (2011) also provided evidence in their study that firms who do not use their cash for paying dividends and making acquisitions, use it for capitalizing on other investment opportunities.

There are three major theories that majorly explain the cash-holding determinants; these are pecking order theory, the trade-off model and the free cash flow theory. According to the free cash-flow theory, it is found that managers use cash-holdings to satisfy their own interests rather than focusing on shareholders' interests, thereby giving rise to conflict of interest between managers and shareholders (Harford et al. 2014). According to the explanation proposed by free 
cash flow theory, companies which possess higher opportunities for growth usually are faced with high agency cost as well. Hence, such companies tend to hold more cash reserves as a proactive measure for securing capital. Furthermore, it can be explained that when managers and shareholders have conflicts between their interests, management use the discretion to store as much as cash as possible for pursuing their own goals instead of the shareholders'. Cash is not only seen as a means of making profit, but it is also considered to be invested in projects which are deemed to be risky and investors are unwilling to raise capital for those. Apart from these, cash is also held by the board of a company as a strategy of risk aversion.

While according to Myers and Majluf (1984) who proposed the pecking order theory, it issuggested that managers follow a specific order for capital financing such that the cost of information asymmetry is minimized along with minimizing other financial costs as well. Pecking order theory implies that internal financing is usually preferred by firms, thus directors take actions such as adjusting dividend payouts so that the operations can be financed internally instead of selling ordinary shares to external shareholders. It helps in preventing significant change in a firm's total number of shares. They highlighted that while considering external financing, the safest securities must be considered as a priority to be issued. Hence, in the light of this theory, debt is considered to be the safest security whereas equity must be considered as last option. However, it has also been argued that the optimal level of cash-holding is none other than holding cash as a buffer between investment needs and retention of profits.

With respect to the trade-off theory, it is suggested that firms have two options for financing their operation; either through borrowing or through retaining cash, however both options have their own pros and cons. Trade-off theory of Fresard (2010), which is also known as transaction cost model, explains that companies determine cash-holding level for themselves through keeping a balance between profit margin arising from holding cash and the marginal cost for holding highly liquid assets. High profit margin means that chances of financial distress are reduced, indicating that company can make optimal investments and can avoid costs associated with liquidation of assets or external financing. High cost of external funding is because of the fact that market is imperfect thus making it difficult for firms to access capital markets. When benefits of holding cash gives less benefits as compared to investment elsewhere in an equally risky condition, then the marginal cost becomes opportunity cost for a company with respect to holding cash (Ferreira \& Vilela, 2004).

\section{H1: Cash-holding has a significant impact on financial performance of firms. 2.2 Moderating role of Corporate Governance}

Corporate governance is important in times of economic prosperity as well as during times of economic crisis, depending upon the firm-specific operational factors and economic environment (Choi \& Wang, 2009). In the absence of good corporate governance in an adverse economic situation, the result is finance-specific distress that ultimately leads to crisis in the external environment and overall economy. In addition to this, the stock market is also heavily dependent on corporations' performance, as observed by Chen Fan \& Yang (2014) and some other researchers. These scholars also highlighted that because of the limited availability of information through research tools like surveys, the obtained results are generalized for entire population although the sample chosen for study is usually small. They also observed that many of the studies are bound by economic limitations as well. In another study, Pham, Suchard \& Zein (2011) adds that many studies have used superficial data and thus they were not able to handle the 
complexity of the broad aspects associated with corporate governance and its impact on a firm's performance. Moreover, this inconsistency is also contributed by the volatile nature of performance measures. Therefore, a sensible approach will be to adopt multiple techniques in order to achieve greater accuracy in results. As observed by Singh and Davidson (2003), corruption can be prevented and management at all levels can benefit from a sound corporate policy. At the same time, good governance policies also results in enhancing a firm's value and reducing the risks associated with investment and financing. Similarly investors are attracted by solid corporate governance policies and it aids them in making their investment decisions (Shen, Lin \& Wang, 2015).

H2: Corporate Governance moderates the association between Cash-holding and firm performance.

\section{Research Methodology}

\subsection{Data and Sample Selection}

Currently, there are 551 firms listed on Pakistan Stock Exchange (PSX). The listed firms are broadly categorized into financial and non-financial firms. Initially, all the financial firms are excluded from the sample because of the difference in the regulatory requirements, complex business operations and type of risks faced by these firms. Further, only those firms are retained which remained listed for all the 12 years in order to avoid survival bias. Therefore, for this study, the research sample comprises of 145 non-financial firms for a period of 12 years i.e. from 20062017. The secondary data of cash-holdings, corporate governance characteristics, and financial performance along-with the control variables is taken from the annual reports of all the listed non-financial firms (Bennette \& Kottasz, 2012). These annual reports are obtained from the PSX, State bank of Pakistan and websites of respective firms.

\subsection{Data Analysis Technique and Econometric Model}

The secondary data obtained from the annual reports of respective companies is analyzed through descriptive and inferential statistics. The previous research studies analyzing the impact of cash holding and firm performance using regression analysis have been criticized by the researchers due to the fact that unobserved heterogeneity associated with endogeneity cannot be controlled (see for instance Nguyen et al., 2019; Harford et al. 2014). In order to cater this issue, Generalized Method of Moments (GMM) is used in this research as proposed by Wintoki et al (2012). The econometric model used in this research is as follows:

$$
A B P_{i t}=\beta_{0+} \beta_{1} C H_{i t}+\beta_{2} C G G I_{i t}+\beta_{3} C H_{i t} * C_{1} I_{i t}+\beta_{4} \text { LEV }+\beta_{5} \text { SIZE }+\beta_{6} \text { GROWTH }+\mu
$$

Where: ABP is the Accounting based Performance (Measured in terms of Return on Assets), $\mathrm{CH}=$ Cash-holding, $\mathrm{CGI}=$ Corporate Governance Index (the index will be calculated using principal component analysis based on the following corporate governance characteristics: Board Independence, CEO Duality, Board Size, Board Meetings, Audit Committee Size, Audit committee Independence, Ownership Concentration, Managerial Ownership), LEV = Leverage, SIZE $=$ Size, GROWTH $=$ Growth of Firm,$\mu=$ Error term . 
Table 2: Correlation Analysis

\begin{tabular}{lcccccr} 
& ROA & CH & CGI & LEV & SIZE & GROWTH \\
\hline ROA & 1.000 & 0.030 & 0.067 & -0.002 & 0.022 & -0.024 \\
CH & 0.030 & 1.000 & -0.064 & -0.010 & -0.144 & 0.000 \\
CGI & 0.067 & -0.064 & 1.000 & 0.010 & 0.322 & 0.057 \\
LEV & -0.002 & -0.010 & 0.010 & 1.000 & 0.010 & -0.017 \\
SIZE & 0.022 & -0.144 & 0.322 & 0.010 & 1.000 & 0.108 \\
GROWTH & -0.024 & 0.000 & 0.057 & -0.017 & 0.108 & 1.000 \\
\hline Whe ROA
\end{tabular}

Where ROA $=$ Return on Assets, $\mathrm{CH}=$ Cash Holding, CGI $=$ Corporate Governance Index, LEV $=$ Leverage, Size $=$ Size of Firm, Growth $=$ Growth of Firm

Table 2 represents that the correlation value is of $\mathrm{CH}$ and $\mathrm{ROA}$ is 0.030 which shows that a positive relationship exist between $\mathrm{CH}$ and ROA. The correlation of CGI and ROA is 0.067 which states a positive association between CGI on ROA. The correlation is -0.064 of CGI and $\mathrm{CH}$ which explains that a negative association of CGI on $\mathrm{CH}$. The correlation value of LEV and ROA is -0.002 which shows a negative relation of LEV on ROA. The correlation value is -0.010 of LEV and $\mathrm{CH}$ which demonstrates a negative association between LEV and $\mathrm{CH}$. The correlation value between LEV and CGI is 0.010 that indicates a positive correlation amongst LEV and CGI. The value of correlation lies amongst SIZE and ROA is 0.022 which means there is a positive relationship between SIZE and ROA. The correlation lying between SIZE and $\mathrm{CH}$ is -0.144 which states a negative association of SIZE and CH. The value of correlation of SIZE and CGI is 0.322 that indicates positive impact of SIZE on CGI. The correlation of SIZE and LEV is 0.010 that shows a positive association present between these variables. The value of correlation of GROWTH and ROA is -0.024 that shows negative negligible relationship of GROWTH on ROA. The correlation of GROWTH and $\mathrm{CH}$ is 0.000 which shows a positive association of GROWTH and CH. The Correlation value lying between GROWTH and CGI is 0.057 which exhibits positive association between GROWTH and CGI. The value of correlation of GROWTH and LEV is -0.017 that indicates a negative relationship between them. The correlation value between GROWTH and SIZE is 0.108 that shows a positive low association amongst GROWTH and SIZE. 
Table 3: Regression Analysis Cash Holding and Firm Performance with moderating role of Corporate Governance

\begin{tabular}{|c|c|c|c|}
\hline Variable & Coefficient & t-Statistic & Prob. \\
\hline $\mathrm{C}$ & -0.689931 & -3.712556 & 0.0002 \\
\hline $\mathrm{CH}$ & 1.800259 & 3.472559 & 0.0005 \\
\hline CGI & 0.018195 & 3.047779 & 0.0023 \\
\hline $\mathrm{CH}^{*} \mathrm{CGI}$ & -0.856700 & -2.658874 & 0.0079 \\
\hline LEV & $9.30 \mathrm{E}-06$ & 0.899026 & 0.3688 \\
\hline SIZE & 0.072740 & 4.050021 & 0.0001 \\
\hline GROWTH & 0.020228 & 2.293517 & 0.0220 \\
\hline Adjusted R-Square & 0.379740 & & \\
\hline Probability (F-Statistics) & 0.000000 & & \\
\hline
\end{tabular}

Where ROA = Return on Assets, $\mathrm{CH}=$ Cash Holding, $\mathrm{CGI}=$ Corporate Governance Index, $\mathrm{CH}^{*} \mathrm{CGI}=$ Interaction term of Moderator, $\mathrm{LEV}=$ Leverage, Size $=$ Size of Firm, Growth $=$ Growth of Firm

Interpretation:

The value of R-square represents that $37.97 \%$ variation in Return on Assets (ROA) is caused by the variation in cash holdings $(\mathrm{CH})$ and other variables used in the model. The value of beta coefficient for $\mathrm{CH}$ is 1.80 , which means that 1 unit increase in $\mathrm{CH}$ causes 1.80 units increase in ROA.The p-value for $\mathrm{CH}$ is 0.0005 (less than 0.05 ) and the $\mathrm{t}$-value of 3.472 which is greater than 1.96 indicates that $\mathrm{CH}$ has a significant positive impact on firm performance (FP). These results indicate that firms holding greater cash have better performance as compared to their counterparts having lower cash. It is because of the fact that availability of cash on one hand improves the liquidity, ensures smooth routine activities and on the other hand helps the firms to avail upcoming market opportunities. The positive relationship between cash holding and financial performance of firms is in congruence with most of the prior research studies. For instance, Saddour (2006), found this association to be positive in case of French stock exchange listed firms for the period of 1988-2002, showing that increasing level of cash reserves tend to improve operational efficiency of firms. Likewise, the findings of Bates et al. (2009) indicated that companies practice holding cash more whenever their cash flow becomes riskier. These findings support that firms take precautionary measures for holding cash and emphasize positive impact of cash-holdings on a firm's performance.

The value of standardized beta of corporate governance index (CGI) represents the impact of CGI index on ROA. Since the value of beta is 0.018 which means that 1 unit increase in CGI causes 0.018 increase in ROA. The p-value for CGI index is 0.0023 which is lower than 0.05 and t-value is 3.04 which is higher than 1.96 shows that CGI index has a significant positive impact on ROA. The positive relationship of CGI and ROA suggest that with the strengthening of corporate governance practices, financial performance of firms have improved. As observed by Kakanda \& 
Salim (2017), good governance policies result in enhancing firm's performance and reducing the risks associated with investment and financing decisions (Jakpar et al., 2019). Similarly, investors are attracted by strong corporate governance policies and it facilitates them in making better investment decisions (Patel, 2018). Edmans \& Holderness (2017) highlight in their study that management benefits from a sound corporate governance policy and it results in prevention of corrupt practices. Also, it results in enhancing the value of a firm while subsequently reducing the financial and investment related risks (Hossain \& Hammami, 2009). Similarly, it was also pointed out by Shen et al. (2006) that investors analyze the corporate governance policy while making decision to invest in a company.

Different companies follow different governance practices. Such practices also vary from industry to industry and country to country, resulting in different institutional, regulatory and statutory settings everywhere. Culture specific factors also create changes in governance policies. The research of Liu, Yang \& Zhang (2012) compares firm performance in a sample of 27 developed countries. It reveals that countries offering minority shareholder protection have high valued firms. Similarly, Munisi \& Randoy (2013) also argued that countries where there is a fragile frail statutory framework gives more importance to corporate governance and in these countries, there exists a positive relationship between firm's performance and firm's value in the market. Earlier, the study of Fama and Jensen, (1983) emphasized that due to effective implementation of corporate governance, managers and other executives of a firm do not indulge into practicing their self-interests at the cost of organizational interest.

The value of standardized beta for interaction term ( $\left.\mathrm{CH}^{*} \mathrm{CGI}\right)$ represents the impact of $\mathrm{CH}^{*} \mathrm{CGI}$ on ROA. The value for beta is 0.0079 which means that 1 unit increase in $\mathrm{CH}^{*} \mathrm{CGI}$ causes 0.0079 increase in ROA.The p-value for $\mathrm{CH}^{*} \mathrm{CGI}$ is 0.0079 which is less than 0.05 hence $\mathrm{CH}^{*} \mathrm{CGI}$ contributes significant to the model. It is determined that Corporate Governance (CG) moderates the relationship of CH-CGI. The $\mathrm{t}$-value of -2.65 is greater than 1.96 , hence $\mathrm{CH}^{*} \mathrm{CGI}$ significantly moderates the association between $\mathrm{CH}$ and ROA. However, the negative value suggests that the moderator weakens the relationship between the independent and dependent variables. Corporate governance is important in times of economic prosperity as well as during times of economic crisis, depending upon the firm-specific operational factors and economic environment (Choi \& Wang, 2009). In the absence of good corporate governance in an adverse economic situation, the result is finance-specific distress that ultimately leads to crisis in the external environment and overall economy. In addition to this, the stock market is also heavily dependent on corporations' performance, as observed by Chen Fan \& Yang (2014) and some other researchers.

These scholars also highlighted that because of the limited availability of information through research tools like surveys, the obtained results are generalized for entire population although the sample chosen for study is usually small. They also observed that many of the studies are bound by economic limitations as well. In another study, Pham, Suchard \& Zein (2011) adds that many studies have used superficial data and thus they were not able to handle the complexity of the broad aspects associated with corporate governance and its impact on a firm's performance. Moreover, this inconsistency is also contributed by the volatile nature of performance measures. Therefore, a sensible approach will be to adopt multiple techniques in order to achieve greater accuracy in results.

As observed by Singh and Davidson (2003), corruption can be prevented and management at all levels can benefit from a sound corporate policy. At the same time, good governance policies also results in enhancing a firm's value and reducing the risks associated with investment and 
financing. Similarly, investors are attracted by solid corporate governance policies and it aids them in making their investment decisions (Shen, Lin \& Wang, 2015). The value of beta coefficient for LEV represents the impact of leverage on CFP. The value ofstandardized beta for Lev is 9.30E-06 which means that 1 unit increase in LEV causes 9.30E-06 increase in ROA. The p-value for LEV is 0.3688 which is greater than 0.05 and t-value of 0.8990 is less than 1.96 indicates that leverage has an insignificant impact on ROA. According to Modigliani \& Miller Irrelevance theory, it is argued that firm performance is not associated with gearing level. It means that financial performance may be independent of the fact that whether firms are financed through or debt or equity.

The value of standardized beta for SIZE represents the impact of firm size on ROA. The value of beta for firm size is 0.072 which means that 1 unit increase in SIZE causes 0.072increase in ROA of firms. The p-value for size is 0.0001 which is less than 0.05 hence size contributes significant impact on ROA. The value of $t$ is 4.05 which is greater than 1.96 hence size of firms contributes significantly to ROA. The firms that are larger in size have the positive impact on ROA i.e., the performance of non-financial firms having greater assets is better than other firms because of their improved ability to generate revenue. Similarly, the larger firms have greater market share, market penetration and product portfolio that enhances their financial performance. The beta value of for GROWTH represents the impact of growth of firms on ROA. The value of beta for growth of firms is 0.02 which means that 1 unit increase in GROWTH causes 0.02 increase ROA. The p-value for growth is 0.0220 which is less than 0.05 so growth of the firms contributes significantly to financial performance. The t-value of 2.29 which is greater than 1.96 indicates significant impact of GROWTH on ROA. The results indicate that firms in growth stage have better performance in terms of ROA.

\section{Conclusion}

The results of this research study suggest that cash holding has a significant positive impact on financial performance of firms. These results indicate that firms holding greater cash have better performance as compared to their counterparts having lower cash (La Rocca \& Cambrea, 2019). It is because of the fact that availability of cash on one hand improves the liquidity, ensures smooth routine activities and on the other hand helps the firms to avail upcoming market opportunities. The positive relationship between cash holding and financial performance of firms is in congruence with most of the prior research studies. For instance, Saddour (2006), found this association to be positive in case of French stock exchange listed firms for the period of 19882002, showing that increasing level of cash reserves tend to improve operational efficiency of firms. Likewise, the findings of Bates et al. (2009) indicated that companies practice holding cash more whenever their cash flow becomes riskier. These findings support that firms take precautionary measures for holding cash and emphasize positive impact of cash-holdings on a firm's performance.

Moreover, the significant impact of moderator suggest that financial performance of firms have improvedwith the strengthening of corporate governance practices. As observed by Kakanda \& Salim (2017), good governance policies result in enhancing firm's performance and reducing the risks associated with investment and financing decisions (Jakpar et al., 2019). Similarly, investors are attracted by strong corporate governance policies and it facilitates them in making better investment decisions (Patel, 2018). Edmans \& Holderness (2017) highlight in their study that management benefits from a sound corporate governance policy and it results in prevention of corrupt practices. Also, it results in enhancing the value of a firm while subsequently reducing the 
financial and investment related risks (Hossain \& Hammami, 2009). Similarly, it was also pointed out by Shen et al. (2006) that investors analyze the corporate governance policy while making decision to invest in a company. The future researchers may use a larger data set by comparing the cash holding practices of other emerging economies. Moreover, it would be interesting to analyze the linear/non-linear behaviour of firm cash holding and firm performance. Adding further, the cash holding pattern of various industries can be analyzed to get insights of industry practices.

\section{References}

Abdumavlonov, A. A. (2012). Corporate Governance Failures as a Reason for UK Banking Crisis. Available at SSRN 2059839.

Ali, S., Ullah, M., \& Ullah, N. (2016). Determinants of Corporate Cash Holdings: A Case of Textile Sector in Pakistan'. Available at SSRN 2728200.

Al-Najjar, B. (2013). The financial determinants of corporate cash holdings: Evidence from some emerging markets. International business review, 22(1), 77-88.

Al-Najjar, B., \& Clark, E. (2017). Corporate governance and cash holdings in MENA: Evidence from internal and external governance practices. Research in international business and finance, 39, 1- 12.

Bates, T. W., Kahle, K. M., \&Stulz, R. M. (2009). Why do US firms hold so much more cash than they used to?. The journal of finance, 64(5), 1985-2021.

Bennett, R., \&Kottasz, R. (2012). Public attitudes towards the UK banking industry following the global financial crisis. International Journal of Bank Marketing.

Bolton, P., Chen, H., \& Wang, N. (2011). A unified theory of Tobin's q, corporate investment, financing, and risk management. The journal of Finance, 66(5), 1545-1578.

Campello, M., Giambona, E., Graham, J. R., \& Harvey, C. R. (2011). Liquidity management and corporate investment during a financial crisis. Thereview of financial studies, 24(6), 1944-1979.

Chen, C. L., Fan, H. S., \& Yang, Y. M. (2014). The effects of corporate governance and accounting rule changes on derivatives usage. Review of Derivatives Research, 17(3), 323-353.

De Haan, J., \&Vlahu, R. (2016). Corporate governance of banks: A survey. Journal of Economic Surveys, 30(2), 228-277.

Dittmar, A., \& Mahrt-Smith, J. (2007). Corporate governance and the value of cash holdings. Journal of financial economics, 83(3), 599-634.

Doan, T. (2020). The effect of cash holdings on firm performance: Evidence from Vietnam listed firms. Accounting, 6(5), 721-726.

Ducassy, I., \&Montandrau, S. (2015). Corporate social performance, ownership structure, and corporate governance in France. Research in International Business and Finance, 34, 383-396.

Edmans, A., \& Holderness, C. G. (2017). Blockholders: A survey of theory and evidence. In The handbook of the economics of corporate governance (Vol. 1, pp. 541-636). NorthHolland.

Fama, E \& Jensen, M. (1983). Separation of ownership and control. Journal of Law \& Economics 26, pp. 301-349.

Ferreira, M. A., \&Vilela, A. S. (2004). Why do firms hold cash? Evidence from EMU countries. European financial management, 10(2), 295-319. 
Francis, B., Hasan, I., \& Wu, Q. (2015). Professors in the boardroom and their impact on corporate governance and firm performance. Financial management, 44(3), 547-581.

Fresard, L. (2010). Financial strength and product market behavior: The real effects of corporate cash holdings. The journal of finance, 65(3), 1097-1122.

Graham, J. R., \& Leary, M. T. (2018). The evolution of corporate cash. The review of financial studies, 31(11), 4288-4344.

Harford, J., Klasa, S., \& Maxwell, W. F. (2014). Refinancing risk and cash holdings. The journal of finance, 69(3), 975-1012.

Harford, J., Mansi, S. A., \& Maxwell, W. F. (2008). Corporate governance and firm cash holdings in the US. Journal of financial economics, 87(3), 535-555.

Hossain, M., \&Hammami, H. (2009). Voluntary disclosure in the annual reports of an emerging country: $\quad$ The case of Qatar. Advances in Accounting, 25(2), 255-265.

Huang-Meier, W., Lambertides, N., \&Steeley, J. M. (2016). Motives for corporate cash holdings: the CEO optimism effect. Review of quantitative finance and accounting, 47(3), 699-732.

Jabbouri, I., \& Almustafa, H. (2020). Corporate cash holdings, firm performance and national governance: evidence from emerging markets. International Journal of Managerial Finance.

Jakpar, S., Tinggi, M., Johari, A., \&Myint, K. T. (2019). Analysis of corporate governance and firm performance: Evidence from Malaysian listed companies. International journal of business and social science, 10(1).

Jensen, M. C., \&Meckling, W. (1976). H. (1976). Theory of the firm: managerial behavior, agency costs and ownership structure: Journal of Finance Economics, 3.

Kakanda, M. M., \& Salim, B. (2017). Corporate governance, risk management disclosure, and firm performance: a theoretical and empirical review perspective. Asian economic and financial review, 7(9), 836.

Kim, J., Kim, H., \& Woods, D. (2011). Determinants of corporate cash-holding levels: An empirical examination of the restaurant industry. International journal of hospitality management, 30(3), 568-574.

Krenn, M. (2016). Convergence and divergence in corporate governance: An integrative institutional theory perspective. Management research review, 39(11), 1447-1471.

La Rocca, M., \& Cambrea, D. R. (2019). The effect of cash holdings on firm performance in large Italian companies. Journal of International Financial Management \& Accounting, 30(1), 30-59.

Liu, W., Yang, H., \& Zhang, G. (2012). Does family business excel in firm performance? An institution- based view. Asia Pacific Journal of Management, 29(4), 965-987.

Munisi, G., \&Randøy, T. (2013). Corporate governance and company performance across SubSaharan African countries. Journal of Economics and Business, 70, 92-110.

Myers, S. C., \&Majluf, N. S. (1984). Corporate financing and investment decisions when firms have information that investors do not have. Journal of financial economics, 13(2), 187-221.

Nguyen Thanh, C. (2019). Optimal Cash Holding Ratio for Non-Financial Firms in Vietnam Stock $\quad$ Exchange Market. Journal of risk and financial management, 12(2), 104.

Patel, M. A. (2018). Corporate Governance and Financial Performance in an Emerging Economy

Context: Evidence from Pakistan's Food, Personal Care and Cement Sectors. South Asian Journal of Management, 25(1). 
Pham, P. K., Suchard, J. A., \&Zein, J. (2011). Corporate governance and alternative performance measures: evidence from Australian firms. Australian Journal of Management, 36(3), 371-386.

Saddour, K. (2006). The determinants and the value of cash holdings: Evidence from French firms. Cahier de recherche n, 6, 1-30.

Sheikh, N. A., \& Khan, M. I. (2016). Effects of excess cash, board attributes and insider ownership on firm value: evidence from Pakistan. Australasian accounting, business and finance journal, 10(1), 29-39.

Shen, C. H., Lin, C. Y., \& Wang, Y. C. (2015). Do strong corporate governance firms still require political connection, and vice versa? International Review of Economics \& Finance, 39, 107-120.

SHEN, H., \& JIN, T. (2006). An Analysis of Corporate Social Responsibility Disclosures of Listed Companies in China [J]. Audit \& Economy Research, 3.

Singh, M., \& Davidson III, W. N. (2003). Agency costs, ownership structure and corporate governance mechanisms. Journal of Banking \& Finance, 27(5), 793-816.

Wintoki, M. B., Linck, J. S., \& Netter, J. M. (2012). Endogeneity and the dynamics of internal corporate governance. Journal of Financial Economics, 105(3), 581-606. 